\title{
Growth and yield of soybean cultivated in agroforestry systems
}

\author{
Edinéia de Cristo ${ }^{\prime *}$ (1), Jaqueline Sgarbossa ${ }^{1}$, Felipe Schwerz ${ }^{2}$ Claiton Nardini ${ }^{3}$, \\ Liliane Bárbara Tibolla', Braulio Otomar Caron ${ }^{1}$
}

$10.1590 / 0034-737 X 202067030001$

\begin{abstract}
Agriculture has caused numerous concerns regarding the preservation of natural resources. In this context, agroforestry systems are emerging as a more sustainable alternative. The present study aimed to evaluate growth characteristics, radiation use efficiency, biomass partition, and yield of soybean grown in two agroforestry systems and full sun. A field experiment was conducted in Southern Brazil during the 2014/2015 crop year, in which transmissivity of solar radiation, leaf area index, radiation use efficiency, and yield of soybean were evaluated. The solar radiation dynamics varied among the study factors, mainly due to the agroforestry arrangements. Shading influenced the leaf area index, radiation use efficiency, biomass partition, and soybean yield. Based on the soybean yield values generated in this study, the use of more spaced agroforestry arrangements and Peltophorum dubium forest species is recommended. However, because the yield values were below the expected levels, it is not yet possible to confirm the full potential of soybean crop in agroforestry systems. Thus, new studies should be conducted in order to generate alternatives that make soybean cultivation feasible in agroforestry systems, such as assessing the use of more spaced agroforestry arrangements, the insertion of the soybean crop in the initial years of cultivation of agroforestry, as well as reduce intraspecific competition by decreasing the plant population of the crop.
\end{abstract}

Keywords: biomass partition; leaf area index; radiation use efficiency; transmissivity; Glycine max.

\section{INTRODUCTION}

The popularity of agroforestry systems (AS) has been increasing in Brazil, especially in small farms, as an alternative for intercropping between annual and perennial species (Balbino et al., 2011). Agriculture has triggered numerous concerns regarding the preservation of natural resources. In this context, AS are emerging as a more sustainable alternative to production, where the integration of crops and forests promotes socio-economic benefits such as improvement of the physical, chemical, and biological qualities of the soil, increase in organic matter content, and higher nutrient cycling (Cordeiro et al., 2015).

In AS, interactions occur between the growth and development of intercropping species, for example, tree canopy projection may alter the dynamics of solar radiation. Solar radiation is one of the most influential meteorological elements for plant growth and development and the primary source of energy for photosynthesis. Thus, biomass accumulation is highly dependent on the amount of solar radiation intercepted by the crop canopy as well as its ability to convert the intercepted radiation to dry matter (Van Heerden, 2010).

Soybean (Glycine max), is an higly important oilseed for the Brazilian economy. The area planted with this crop increased $2 \%$ in the 2018/2019 crop season when compared to the 2017/2018 one (CONAB, 2019). The main reasons for this increase are the ease grain market and high crop profitability. Thus, the insertion of soybean in AS may be an alternative for expanding the cultivation area, by inserting marginalized areas into the production system, reducing the exploitation of new areas, and helping to maintain biomes (Sgarbossa et al., 2018).

\footnotetext{
Submitted on September 10th, 2019 and accepted on April 14th, 2020.

Universidade Federal de Santa Maria, Departamento de Ciências Agronômicas e Ambientais, Frederico Westphalen, Rio Grande do Sul, Brazil. edineia_015@hotmail.com; sgarbossajs@yahoo.com; lilitibolla@ hotmail.com; otomarcaron@yahoo.com.br

${ }^{2}$ Universidade Federal de Lavras, Departamento de Engenharia Agrícola, Lavras, Minas Gerais, Brazil. felipe_schwerz@hotmail.com

${ }^{3}$ Universidade Federal de Santa Maria, Departamento de Engenharia Florestal, Frederico Westphalen, Rio Grande do Sul, Brazil. claitonnardini@live.com

*Corresponding author: edineia_015@hotmail.com
} 
According to Varella et al. (2010), the interception of solar radiation by forest species at levels above $50 \%$ may directly affect the growth of species growing in the understory. Under limited natural resource conditions, such as water stress, integrated systems tend to optimize production through differentiated use of factors and recirculation of available productive potentials between forest and agricultural components (Macedo et al., 2004).

Previous studies conducted in AS have shown changes in crop characteristics, such as absolute growth rate and relative growth rate of sugarcane (Schwerz et al., 2018), leaf area index and wheat yield (Duan et al., 2019) and soybean yield (Werner et al., 2017; Caron et al., 2018; Sgarbossa et al., 2018). The authors attributed these responses to the reduced solar radiation incidence in the AS understory. However, there is limited information on the effects of shading on growth and radiation use efficiency of soybean grown in AS.

Little attention has been given to the use of different forest species and agroforestry arrangements and the impacts on understory microclimate conditions, as well as the effect of these changes on the growth and yield of intercropping species. Thus, the following hypothesis was generated: i) dynamics of solar radiation, growth and yield of soybean are modified by shading, due to the interactions between the different plant strata. In order to meet this hypothesis, the present study aimed to evaluate the characteristics of growth, radiation use efficiency, and yield of soybean grown in different arrangements of agroforestry and full sun.

\section{MATERIAL AND METHODS}

\section{Study area and experimental design}

A field study was conducted in the city of Frederico Westphalen, RS, Brazil, under geographic coordinates of $27^{\circ} 232263 \mathrm{~S}$ and $53^{\circ} 252433 \mathrm{~W}$ and altitude of $490 \mathrm{~m}$ above sea level. According to the Köppen climate classification system, the region's climate is Cfa, i.e., humid subtropical, with an average annual temperature of 19.1 ${ }^{\circ} \mathrm{C}$, ranging between 0 and $38^{\circ} \mathrm{C}$ and a cumulative annual rainfall of $2.040 \mathrm{~mm}$ (Alvares et al., 2013). The soil of the experimental area is a typical Eutrophic Litolic Neossol (Soil Survey Staff, 2014), with a pH in water of 5.2, $4.5 \mathrm{mg}$ $\mathrm{L}^{-1}$ of $\mathrm{P}$ (Mehlich), $56.5 \mathrm{mg} \mathrm{L}^{-1}$ of $\mathrm{K}, 8.9 \mathrm{cmol}_{\mathrm{c}} \mathrm{L}^{-1}$ of Ca, 1.8 $\mathrm{cmol}_{\mathrm{c}} \mathrm{L}^{-1}$ of $\mathrm{Mg}$, cation exchange capacity (CEC) of 16.75 $\mathrm{cmol}_{\mathrm{c}} \mathrm{L}^{-1}$, base saturation of $64.8 \%$ (BS) and $3.45 \%$ organic matter (OM). Fertilization was based on soil analysis and crop recommendations for the region studied (CQFS, 2004), with $70 \mathrm{~kg}$ of $\mathrm{P}_{2} \mathrm{O}_{5} \mathrm{ha}^{-1}$ and $75 \mathrm{~kg}$ of $\mathrm{K}_{2} \mathrm{O} \mathrm{ha} \mathrm{ha}^{-1}$ applied at sowing.

The experimental design was a randomized block, arranged in a $2 \times 2$ factorial scheme with additional treatment, characterized by two arrangements of AS: Intercrop I $(6 \times 1.5 \mathrm{~m})$ and Intercrop II $(12 \times 3 \mathrm{~m})$; two forest species, Peltophorum dubium, designated (P. dubium) and the hybrid Eucalyptus urophylla S.T. Blake $\times$ Eucalyptus grandis Hill ex Maiden, designated (E. urograndis); and full sun, with four repetitions.

In Intercrop I, the trees were distributed in single rows spaced $6 \mathrm{~m}$ between rows and $1.5 \mathrm{~m}$ between trees in the planting line; soybean was distributed in 8 rows and arranged between the tree rows. In Intercrop II, the trees were distributed in single rows spaced $12 \mathrm{~m}$ apart and $3 \mathrm{~m}$ between trees in the planting line; soybean was distributed in 22 rows arranged between the tree rows. In total, Intercrop I was composed of 12 trees, and Intercrop II by 6 trees for each experimental unit. During the experimental period, all trees were 7-years old.

The planting of forest species was performed in September 2007. The area was prepared by plowing and harrowing, followed by the manual planting of seedlings. Forest species and soybean crop were arranged in an eastwest direction. The allometric characteristics of the 7-yearold trees during the experimental period are listed in Table 1. The height $(\mathrm{H})$, diameter at breast height $(\mathrm{DBH})$, and diameter of the canopy (DC) values of the forest species were measured on 10/20/2014. Tree height was measured from ground level to the top leaves of the crown by using a Vertex II hypsometer. DBH and DC were measured by using a tape measure. The DBH was measured at $1.30 \mathrm{~m}$ from the ground level (Table 1).

Soybean sowing was performed in November 2014, with line spacing of $0.45 \mathrm{~m}$ and 250,000 plants $\mathrm{ha}^{-1}$, and the first soybean line was placed at $1 \mathrm{~m}$ from the tree row. The soybean cultivar used was Nidera A RG 6411, characterized by its determinate growth habit, medium size, early cycle, and good adaptability to the climate of the region. Weed management and phytosanitary control were performed according to crop recommendations (Embrapa, 2006).

After soybean sowing, sample plots of $2 \mathrm{~m}$ were demarcated and distributed at different points under the understory of each experimental unit. In the Intecrop I, four plots were delineated: P1 P2, P3 and P4, which were positioned at a distance of $1.0 \mathrm{~m}, 1.90 \mathrm{~m}, 2.80 \mathrm{~m}$ and $3.70 \mathrm{~m}$ from the tree, respectively. Differently, in the Intercrop II $\mathrm{P} 1, \mathrm{P} 2, \mathrm{P} 3$ and $\mathrm{P} 4$ were positioned at $1.0 \mathrm{~m}, 2.35 \mathrm{~m}, 3.70 \mathrm{~m}$ and $5.05 \mathrm{~m}$, respectively. These sample plots were chosen with the objective to represent existing microclimate conditions in the areas under the canopy of each tree species and arrangements, trying to sample plots represented the existing variability of solar radiation availability and competition among intercropping, the center of the plot and the first sowing line of the annual crop. The arrangement of trees, soybean plants and sample plots are shown in Figure 1. 


\section{Meteorological conditions}

Incident global solar radiation, average solar radiation flux, air temperature (minimum, average and maximum) and rainfall were obtained from an automatic meteorological station of the Brazilian Institute of Meteorology (INMET)), located approximately $1500 \mathrm{~m}$ from the study site. The water balance was run according to Thornthwaite \& Mather (1995) approach at a 10 day time-step from November 2014 to March 2015, covering the whole period for soybean cultivation, considering a soil water holding capacity (SWHC) of $100 \mathrm{~mm}$. The SWHC was estimated considering the following general soil characteristics (Doorenbos \& Kassam, 1994): average SWHC for clayey soils of $2.0 \mathrm{~mm} \mathrm{~cm}^{-1}$; and average values of effective depth of the crop root system (Alfonsi et al., 1990) of $50 \mathrm{~cm}$.

\section{Transmissivity of solar radiation and radiation use efficiency}

To determine the transmissivity of solar radiation into the understory, incident global solar radiation was measured using a pyranometer (LYCOR PY 32164) coupled to a Datalogger (LICOR 1400). The incident solar radiation was quantified outside and under the trees of the agroforestry system, in previously demarcated plots (Figure 1). These plots were selected in order to quantify the distribution of solar radiation in the understory, especially at the points closest to the row of trees. Measurements were made on December 29, 2014, January 13, 2015 and February 10, 2015, from 10 to $12 \mathrm{~h}$. Subsequently, the transmissivity of solar radiation to the understory of each AS arrangement and each species was calculated using the following equation:

Table 1: Height (H), mean diameter of tree canopy (DC), and diameter at breast height (DBH) of P. dubium and E. urograndis trees in two agroforestry arrangements (Intercrop I and Intercrop II)

\begin{tabular}{lcccc}
\hline Arrangements & Species & H $(\mathbf{m})$ & DC $(\mathbf{m})$ & DBH $(\mathbf{c m})$ \\
\hline Intercrop I & P. dubium & 9.4 & 4.84 & 12.44 \\
Intercrop I & E. urograndis & 23.15 & 4.23 & 21.57 \\
Intercrop II & P. dubium & 7.13 & 3.62 & 10.67 \\
Intercrop II & E. urograndis & 24.08 & 4.81 & 32.31 \\
\hline
\end{tabular}

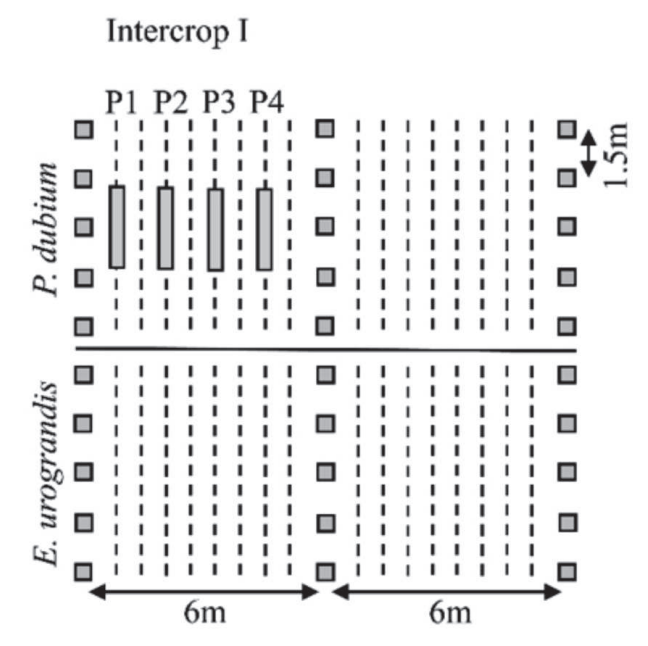

Intercrop I

Full sun
Intercrop II

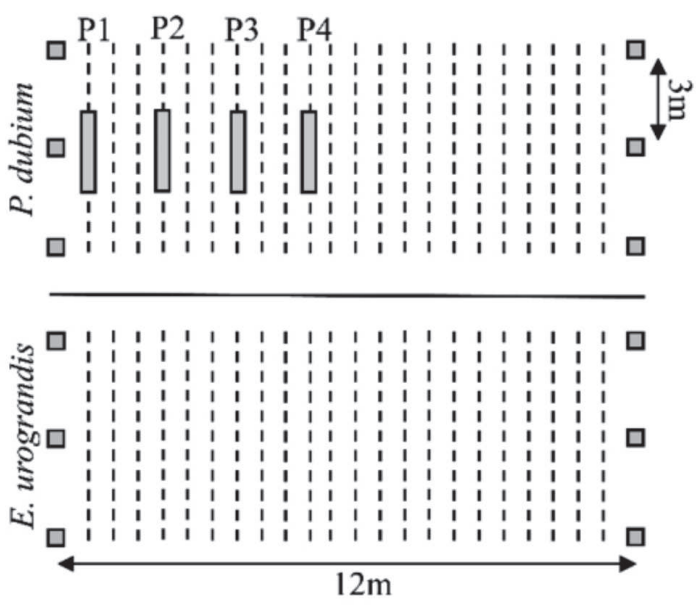

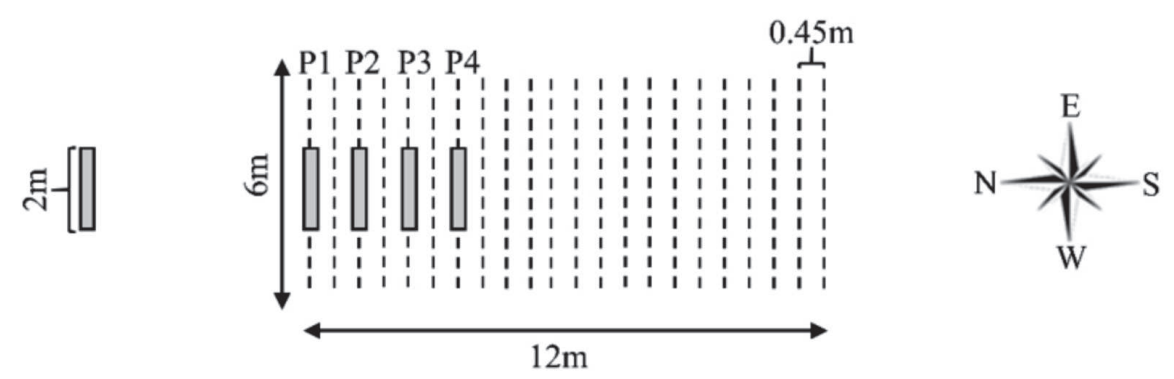

Figure 1: Sketch of an experimental unit of the agroforestry systems (Intercrop I and Intercrop II) and full sun system. Gray squares represent the trees, dashed lines indicate where the soybean was sowed and gray rectangles represent the sample plots. 
$\mathrm{T}=\frac{\mathrm{I}}{\mathrm{I}_{0}} \times 100$

(Equation 1)

where $\mathrm{T}=$ transmissivity $(\%) ; \mathrm{I}=$ solar radiation incident inside of the agroforestry system $\left(\mathrm{W} \mathrm{m}^{-2}\right)$; and $\mathrm{I}_{0}=$ solar radiation incident outside the agroforestry system $\left(\mathrm{W} \mathrm{m}^{-2}\right)$.

The radiation use efficiency was determined by associating the average accumulated dry matter production and intercepted photosynthetically active radiation, according to the model proposed by Monteith (1977).

$\mathrm{TDM}=\mathrm{RUE} * \mathrm{PARi}$

(Equation 2)

where $\mathrm{TDM}=$ total dry matter produced $\left(\mathrm{g} \mathrm{m}^{-2}\right)$; RUE $=$ radiation use efficiency $\left(\mathrm{g} \mathrm{MJ}^{-1}\right)$; and PARi $=$ intercepted photosynthetically active solar radiation $\left(\mathrm{MJ} \mathrm{m}^{-2}\right)$.

The incident photosynthetically active radiation was estimated by considering $45 \%$ global solar radiation (Assis \& Mendez, 1989), not considering the difference between sunny and cloudy days. The intercepted photosynthetically active radiation was estimated by considering the model proposed by Varlet-Grancher et al. (1989):

PARi $=0.95 *($ PARinc $) *\left(1-\mathrm{e}^{\left(-\mathrm{k}^{*} \mathrm{LAI}\right)}\right)$

(Equation 3)

where PARi $=$ intercepted photosynthetically active radiation $\left(\mathrm{MJ} \mathrm{m}^{-2}\right)$; PARinc $=$ incident photosynthetically active radiation; $\mathrm{k}=$ extinction coefficient; and $\mathrm{LAI}=$ leaf area index. The extinction coefficient was calculated for each cropping system by associating the solar radiation incident in the upper layer of the soybean canopy and solar radiation incident in the lower layer of the soybean canopy.

The leaf area index was calculated by considering the relation between the total leaf area and soil area occupied by the plant, according to the following equation:

$\mathrm{LAI}=\mathrm{LA} / \mathrm{SA}$

(Equation 4)
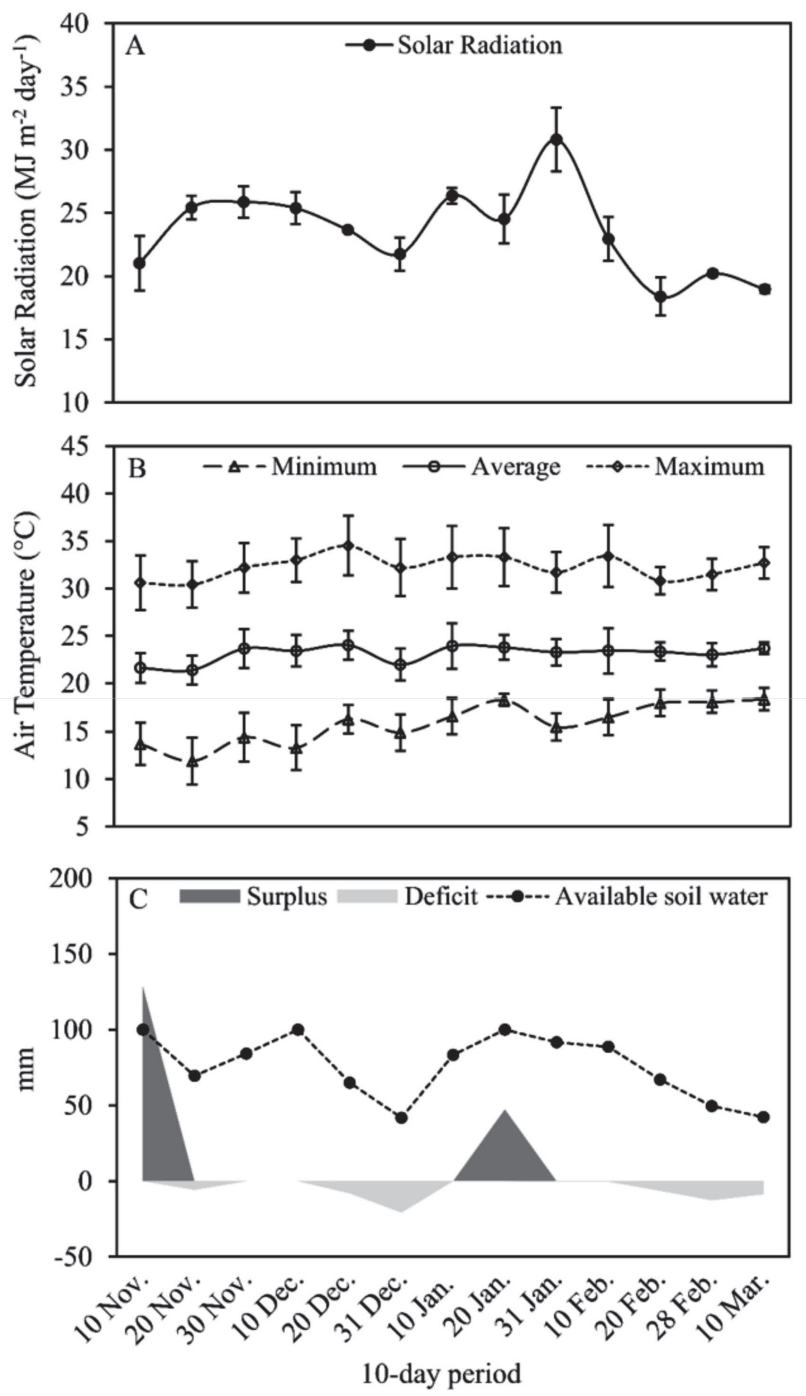

Figure 2: Average solar radiation flux $\left(\mathrm{MJ} \mathrm{m}^{-2} \mathrm{day}^{-1}\right)(\mathrm{A})$; minimum average and maximum (Max) air temperature $\left({ }^{\circ} \mathrm{C}\right)(\mathrm{B})$; and soil water holding capacity $(\mathrm{C})$ (decendial base) during the experimental period. 
where LAI $=$ leaf area index; $\mathrm{LA}=$ total leaf area of the plant $\left(\mathrm{m}^{2}\right), \mathrm{SA}=$ area of soil occupied by the plant $\left(\mathrm{m}^{2}\right)$. The leaf area was measured with a leaf area integrator (LI 3000).

\section{Plant growth and yield}

Plant growth was evaluated fortnightly, from the beginning of vegetative growth to physiological maturation, which resulted in six collections throughout the crop cycle. After collection, the plants were transferred to the laboratory, where each component was separated: cotyledons, stems, branches, leaves, flowers, pods, and senescent leaves. The leaves were considered senescent when $50 \%$ or more of the leaf area was compromised. After the evaluation, the samples were placed in a forced-air circulation oven, with a controlled temperature of around $60^{\circ} \mathrm{C}$, until a constant weight was obtained.

To evaluate the productive performance of soybean, the yield was analyzed by collecting four representative plants from each evaluation plot. Sixteen plants were analyzed in each arrangement and cropping system. The evaluation plots were distributed and demarcated in the understory to obtain the highest possible homogeneity in these cultivation environments (Figure 1). To quantify the grain yield, the total grain obtained from each evaluation plot was weighed, the mass was corrected to $13 \%$ moisture, and the data was upscaled to $\mathrm{kg} \mathrm{ha}^{-1}$.

\section{Statistical analysis}

The data were statistically analyzed using the software "Statistical Analysis System" (SAS, 2003). The Kolmogorov-Smirnov test was performed to verify data normality; analysis of variance (ANOVA) was performed,

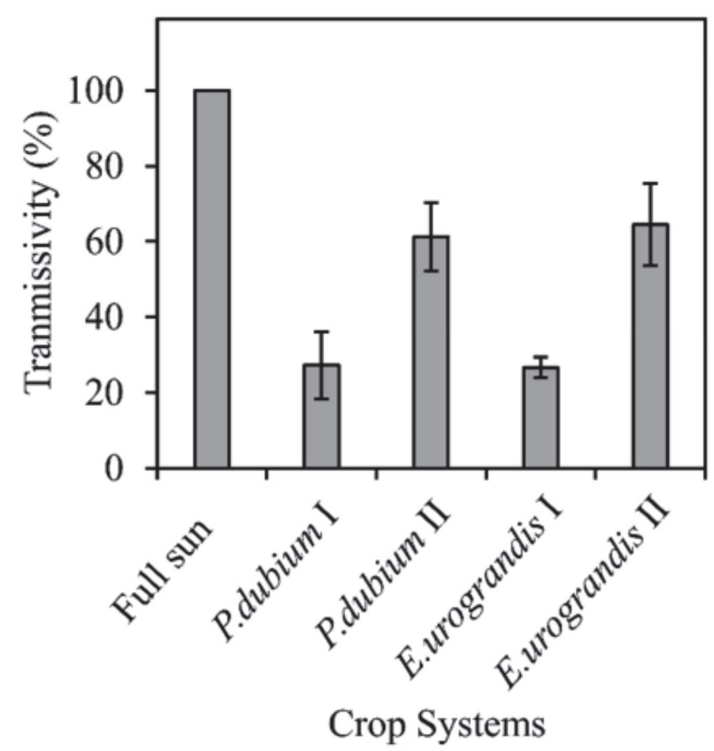

Figure 3: Transmissivity of solar radiation in the understory of $P$. dubium and E. urograndis forest species in different agroforestry arrangements (Intercrop I and Intercrop II). and, according to the $\mathrm{F}$ test, significant differences were found at $5 \%$ probability among the study factors. The Tukey test $(\mathrm{p}<0.05)$ was used to compare arrangements and species, and Dunnett's test $(\mathrm{p}<0.05)$ was used to compare the crop systems.

\section{RESULTS AND DISCUSSION}

\section{Meteorological conditions and dynamics of solar radiation}

During the experimental period, an average air temperature of $22.9^{\circ} \mathrm{C}(16.4-30.7)$, average solar radiation flux of $23.25 \mathrm{MJ} \mathrm{m}^{-2}$ day $^{-1}$ and accumulated rainfall of 663.2 $\mathrm{mm}$ were observed (Figure 2). For suitable growth and development, soybean requires average temperatures between $20^{\circ} \mathrm{C}$ and $30^{\circ} \mathrm{C}$ and accumulated rainfall from 450 to $800 \mathrm{~mm}$ (Embrapa, 2013). Two periods of water deficit were observed, at the initial stages of establishment of the crop and physiological maturation, with little effect on growth, development and yield of the culture.

When analyzing the transmissivity of solar radiation in the different agroforestry arrangements, the highest values were observed in Intercrop II, regardless of the forest species (Figure 3). These results are related to the higher distance between tree rows, which allowed a higher incidence of solar radiation to the understory when compared to the Intercrop I. Similar results were observed by Caron et al. (2018), who studied the dynamics of solar radiation in agroforestry systems and found a higher incidence of radiation in the most spaced arrangement (12 $\times 3 \mathrm{~m})$.

However, we observed similar values for the transmissivity of solar radiation within the understory of the different forest species. These results are attributed to the pruning of the forest component previously sowing of the soybean crop, which minimized the effects of different canopies on the interception of solar radiation.

\section{Plant growth and yield}

For the LAI variable, the highest values were found in the full sun, with a maximum value of 6.36 at 75 days after emergence (DAE) (Figure 4). According to Paciullo et al. (2007), AS have lower LAI because of the lower availability of solar radiation to the annual crop and less interception of photosynthetically active solar radiation. Another aspect for LAI is that the full sun stands out compared to the AS, especially from 45 DAE. This period coincides with the closure of the annual crop canopy, initiating self-shading between plants, increasing intraspecific competition, and further limiting the incidence of solar radiation to the lower soybean canopy stratum.

Similar results have been reported by Petter et al. (2016), who studied the dynamics of photosynthetically active 
radiation (PAR) in soybean leaf layers under different sowing densities and found greater variation between PARi in the lower canopy stratum until 30 DAE. These results were attributed to the absence of self-shading at the beginning of the growth and development of the crop due to the low leaf overlap, increasing the interception flux per leaf unit.

With regard to the AS, Intercrop II showed higher LAI values (by 71.3\%) than Intercrop I. These results can be attributed to the lower competitive capacity among soybean plants under reduced solar radiation availability in less spaced agroforestry plantations $(6 \times 1.5 \mathrm{~m})$. Similar results were obtained by Bosi et al. (2014), who evaluated the biometric characteristics of Brachiaria grass in a silvipastoral system and observed a reduction in LAI when the tree rows were closer.
However, Schmidt et al. (2017) and Bosi et al. (2014) observed that reductions in the availability of solar radiation can lead to an increase in the specific leaf area of understory plants. They highlighted that changes in leaf dimensions are strategies developed by plants to intercept and absorb more solar radiation by increasing leaf surface area.

The highest values of radiation use effiency were verified for E. urograndis Intercrop I ( $\left.3.45 \mathrm{~g} \mathrm{MJ}^{-1}\right)$ and $P$. dubium Intercrop II (2.51 $\left.\mathrm{g} \mathrm{MJ}^{-1}\right)$, and they were $57.53 \%$ and $14.61 \%$ higher than the value obtained from the full sun, respectively (Figure 5). However, it is important to highlight that the higher radiation use efficiency of $E$. urograndis Intercrop I is related to the higher efficiency of soybean plants when converting one unit of solar radiation to one unit of dry matter, but these plants not necessarily presented higher total dry matter.

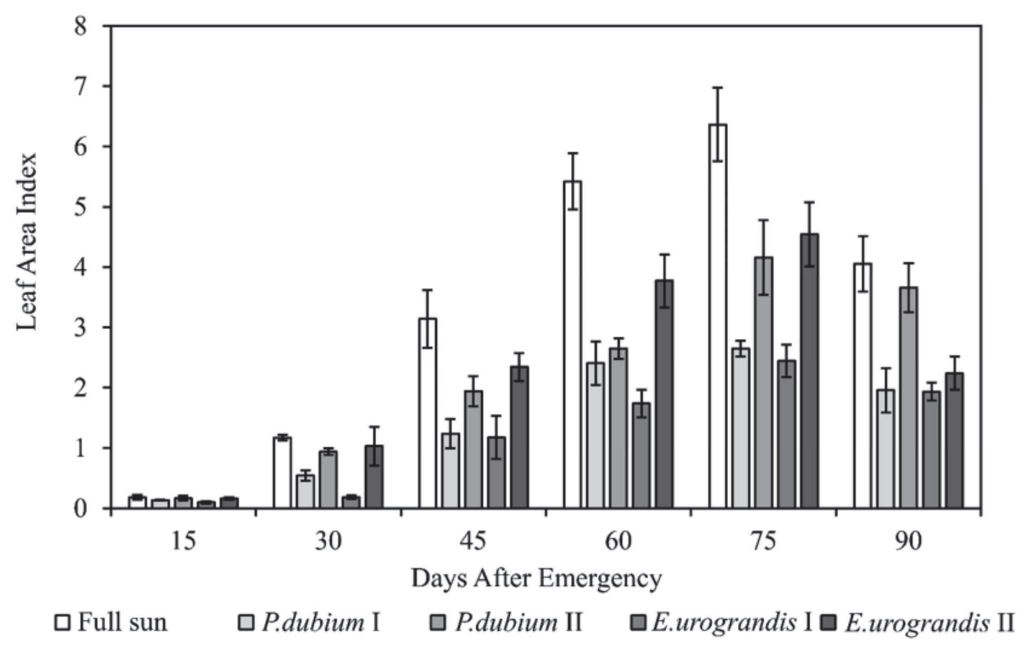

Figure 4: Leaf area index of soybean grown in agroforestry systems and full sun.

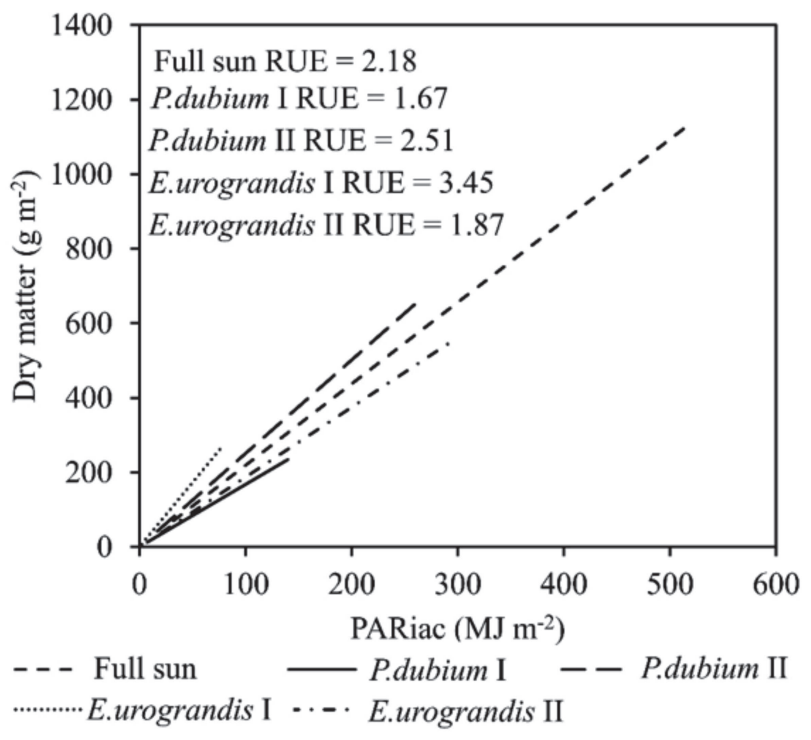

Figure 5: Radiation use efficiency $\left(\mathrm{g} \mathrm{MJ}^{-1}\right)$ of soybean grown in agroforestry systems and full sun. 
The plants cultivated in the full sun, even with lower efficiency in the use of energy units $\left(\mathrm{MJ} \mathrm{m}^{-2}\right)$, showed higher accumulation of dry matter per unit area. These responses are related to the greater availability of solar radiation under the canopy of the full sun, which even being less efficient in converting solar radiation into dry matter had much larger amounts of solar radiation, generating compensation between factors and allowing a greater accumulation of dry matter.

Awais et al. (2017) analyzed the effects of different soybean plant populations on interception capacity and radiation use efficiency and reported values of $1.75 \mathrm{~g} \mathrm{MJ}^{-}$ ${ }^{1}, 1.69 \mathrm{~g} \mathrm{MJ}^{-1}$, and $1.63 \mathrm{~g} \mathrm{MJ}^{-1}$, according to the reduction in plant population. Other studies have reported RUE values of $1.31 \mathrm{~g} \mathrm{MJ}^{-1}$ (Adeboye et al., 2016), $1.44 \mathrm{~g} \mathrm{MJ}^{-1}$ (Singer et al., 2011), and $1.01 \mathrm{~g} \mathrm{MJ}^{-1}$ and $1.77 \mathrm{~g} \mathrm{MJ}^{-1}$ (Van Roekel \& Purcell, 2014) for soybean. The variation between
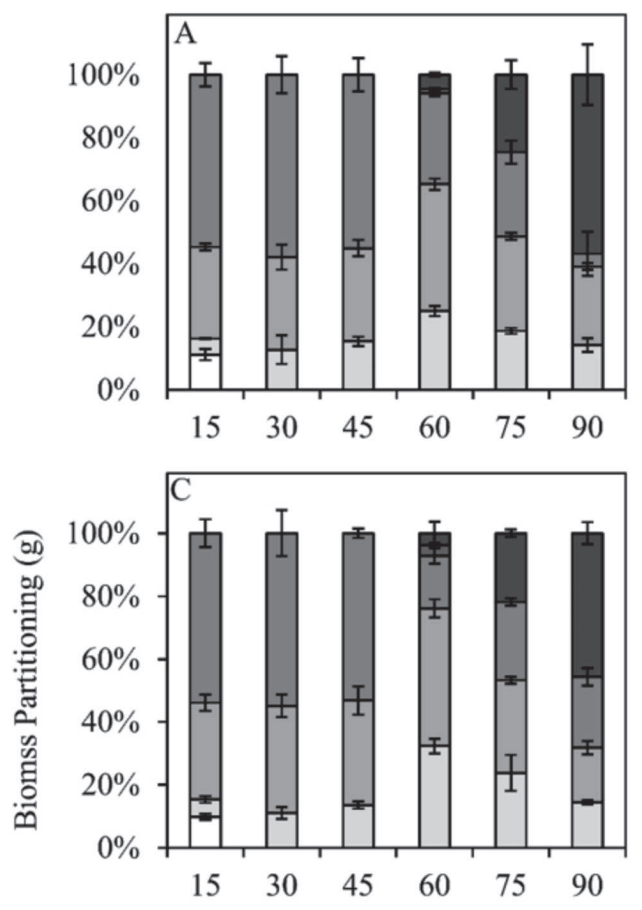

the RUE values reported in this study and those found in the literature can be attributed to the interannual variation in solar radiation as well as changes in the cultivation environment generated by the different plant strata, which affected the conversion capacity of the solar radiation in dry matter.

The accumulation of biomass in the leaves, stem, branches, flowers, and pods was similar during all evaluation periods (Figure 6). In the early stages of plant growth in the AS (up to 45 DAE), the leaves, stems, and branches accounted for, on average, $55 \%, 25 \%$, and $20 \%$ of the accumulated biomass; the same was observed for the full sun until 30 DAE. Furthermore, from 60 DAE, the production of flowers and pods began, reducing the proportion of other compartments. At 90 DAE, a higher proportion of pods compared to other plant organs was observed.
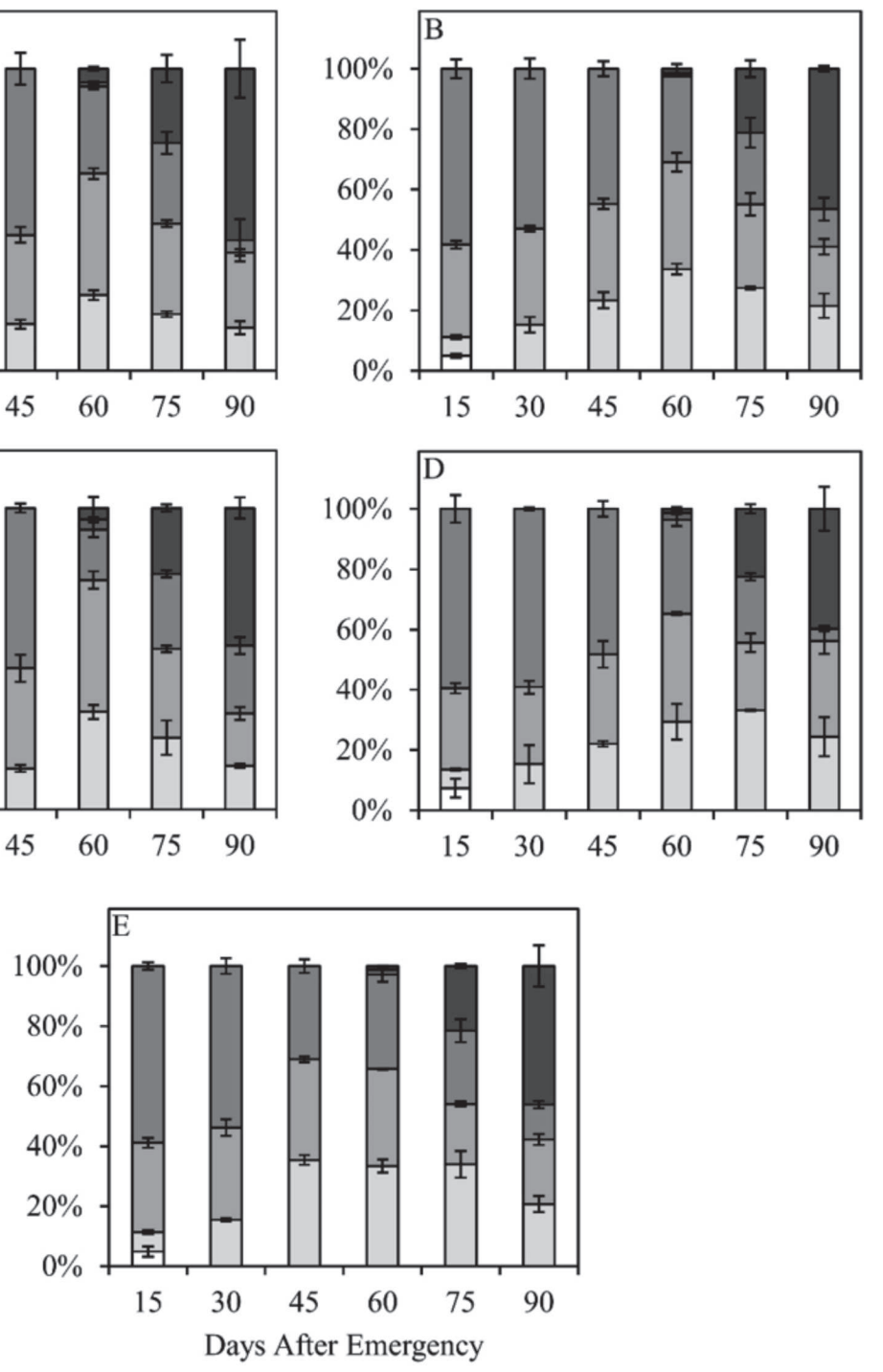

aCot. $\square$ Bran. $\square$ Stal. $\square$ Leaf $\square$ Flo. $\square$ Pods

Figure 6: Biomass partitioning of soybean grown in agroforestry systems and full sun: $P$. dubium Intercrop I (A); $P$. dubium Intercrop II (B); E. urograndis Intercrop I (C); E. urograndis Intercrop II (D); and full sun (E). 
Ahmed et al. (2018) attributed this tendency in the partition of accumulated biomass to crop cycle characteristics, i.e., a higher proportion of leaves, branches, and stems can be observed at the beginning of plant growth because the plants are in the vegetative stage. When they reach the reproductive stage, floral differentiation begins and the accumulation of flowers and pods to the detriment of the other compartments is observed because the order of priority in the partition of photoassimilates is determined by the stage of crop development (Porras et al., 1997). Similar results have been reported by other studies envolving soybean (Gaspar et al., 2017) and sugarcane (Schwerz et al., 2018) crops.

According to ANOVA, no interaction between system $\times$ species for yield was observed, therefore, the main effects were analyzed. Analysis of soybean yield among the different AS arrangements showed a superiority of $63 \%$ for Intercrop II when compared to the Intercrop I (Figure 7A). These results may be related to the higher solar radiation availability for Intercrop II due to the greater distance between the tree rows. Simi- lar results were obtained by Caron et al. (2018), who reported higher yields from less dense crops. Besides that, Werner et al. (2017) observed reductions in soybean yields closer to the tree row. They attributed these results to the competition for natural resources imposed by the trees.

Considering the effect of species on yield, a superiority $57.48 \%$ was observed for $P$. dubium when compared with E. urograndis (Figure 7B). These responses may be related to the intrinsic characteristics of each forest species, especially their competitive capacity. $P$. dubium is a native and deciduous species, with a slightly flattened cylindrical trunk, dichotomous branching, and an average height of 10 to $20 \mathrm{~m}$ (Carvalho, 2002). In contrast, E. urograndis is an exotic species, widely adapted to the region, and has high growth rates in height, stem diameter, and canopy size (Wink et al., 2012), which results in major effects on plant growth in the understory.

The low yield obtained in the understory of $E$. urograndis may be related to the competition for space and nutrients imposed by the roots of trees of this species, which due to its growth characteristics presents
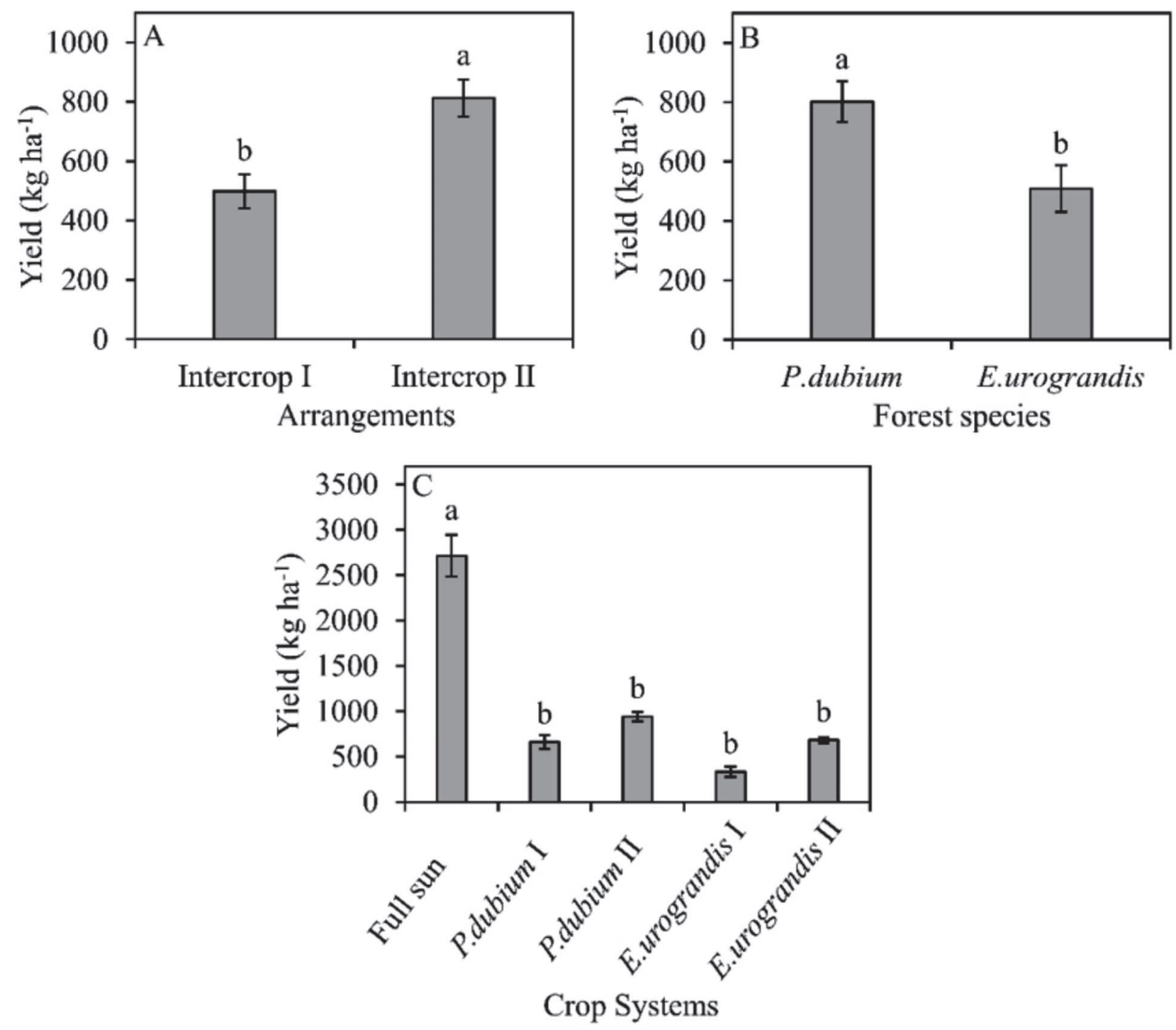

* Means followed by the same letter do not differ according to the Tukey (A and B) and Dunnett (C) tests at $5 \%$ probability of error.

Figure 7: Yield of soybean cultivated in agroforestry systems and full sun: (A) agroforestry arrangements; (B) forest species; (C) crop systems.

Rev. Ceres, Viçosa, v. 67, n.3, p. 165-175, may/jun, 2020 
a more advantageous root system than $P$. dubium, this factor associated with the advanced age of the tree may have intensified the competition. Studies with wheat (Zhang et al., 2013; Wang et al., 2014; Zhang et al., 2016) and cotton (Zhang et al., 2019) identified reductions in root growth and spatial distribution due to the intercropping. Duan et al. (2019), Zhang et al. (2014) and Zhang et al. (2019) point out that, although the mutual competition between roots occurs between different plant strata, the competitive capacity of forest species is much greater than that of annual crops, and tends to increase with the proximity of the tree rows and the age of the planting. Thus, we have highlighted the importance of information on the characteristics of forest species when installing AS.

Soybean yield in the full sun was superior, compared to the other cropping systems (Figure 7C). Diel et al. (2014) evaluated soybean production performance in an agroforestry system and did not find significant reductions in crop yield in the first two years of cultivation. Similarly, Franchini et al. (2014) cultivated soybean in AS with Eucalyptus maculata and found yield reductions after the second year of cultivation. These results were attributed to the reduced size of the forest species in the early years of planting, which results in less competitive capacity for environmental resources.

Solar radiation directly influences crop growth, development, and yield. Thus, the reduced availability of this element justifies most of the results obtained in this study. Based on the transmissivity data, we can observe that the average solar radiation flux within the understory was very close to the trophic limit of the crop, defined as 8.4 $\mathrm{MJ} \mathrm{m}^{-2}$ day $^{-1}$ (Fagan et al., 2013), and this may justify the low yield.

Moreover, given the high demand for grain production, soybean yield is highly reduced when this species is cultivated at radiation transmissivity levels below $50 \%$. The high demand for solar radiation by the crop is due to the bromatological composition of its grains, which consist mainly of proteins that have a high production cost when compared with other substances, such as carbohydrates (the primary product of photosynthesis) (Taiz et al., 2017), justifying the low yield.

\section{CONCLUSIONS}

The dynamics of solar radiation were modified by the agroforestry arrangement and characteristics of the forest species, with a greater effect of the arrangement. The highest incident solar radiation values were obtained in the Intercrop II arrangement and P. dubium forest species. The highest values of leaf area index and yield were verified in the full sun. Regarding to the agroforestry system, the highest values were obtained in the Intercrop II arrangement and $P$. dubium forest.

The highest radiation use efficiency was found in $E$. urograndis Intercrop I because the understory plants were more efficient in converting the reduced radiation levels to dry matter, but it did not result in higher yield.

Based on the soybean yield values generated in this study, the use of more spaced agroforestry arrangements and $P$. dubium forest species is recommended. However, because the yield values were below the expected levels, it is not yet possible to affirm the full potential of the crop in agroforestry systems.

In this context, new research should be conducted in order to generate alternatives that make soybean cultivation feasible in agroforestry systems, such as studying the use of more spaced agroforestry arrangements, the insertion of the crop in the initial years of installation of agroforestry, as well as the reduction of intraspecific competition by decreasing the plant population of the crop.

\section{ACKNOWLEDGEMENTS, FINANCIAL SUPPORT AND FULL DISCLOSURE}

The authors would like to thank the National Council for Scientific and Technological Development (CNPq-Brasil) and the Higher Education Personnel Improvement Coordination (CAPES-Brasil) for their financial support and scholarships at the following levels: Scientific Initiation, Study and Productivity.

The authors report that there is no conflict of interest.

\section{REFERENCES}

Adeboye OB, Schultz B, Adekalu KO \& Prasad K (2016) Impact of water stress on radiation interceptation and radiation use efficiency of soybeans (Glycine max L.Merr.) in Nigeria. Brazilian Journal of Science and Technology, 3:01-15.

Ahmed S, Raza MA, Zhou T, Hussain S, Khalid MHB, Feng L, Wasaya A, Iqbal N, Ahmed A, Liu W \& Yang W (2018) Responses of soybean dry matter production, phosphorus accumulation, and seed yield to sowing time under relay intercropping with maize. Agronomy, 8:01-18.

Alfonsi RR, Pedro MJ, Arruda FB, Ortilani AA, Camargo MBP \& Brunini O (1990) Métodos agrometeorológicos para controle da irrigação. Campinas, IAC. 62p.

Alvares CA, Stape JL, Sentelhas PC, Moraes G, Leonardo J \& Sparovek G (2013) Köppen's climate classification map for Brazil. Meteorologische Zeitschrtf, 22:711-728.

Assis FN \& Mendez MEG (1989) Relação entre radiação fotossinteticamente ativa e radiação global. Pesquisa Agropecuária Brasileira, 24:197-800.

Awais M, Wajid A, Bashir UM, Habib-ur-Rahma M, Raza MAS, Ahmad A, Saleem MF, Hammad HM, Mubeen M, Saeed U, Ashad MN, Fahad S \& Nasim W (2017) Nitrogen and plant population change radiation capture and utilization capacity of sunflower in semi-arid environment. Environmental Science and Pollution Research, 24:17511-17525. 
Balbino LC, Cordeiro LAM, Porfírio-da-Silva V, Moraes A, Martínez GB, Alvarenga RC, Kichel NA, Fontaneli RS, Santos HP, Franchini JC \& Galerani PR (2011) Evolução tecnológica e arranjos produtivos de sistemas de integração lavoura-pecuáriafloresta no Brasil. Pesquisa Agropecuária Brasileira, 46:01-12.

Bosi C, Pezzopane JRM, Sentelhas PC, Santos PM \& Nicodemo MLF (2014) Produtividade e características biométricas do capim-braquiária em sistema silvipastoril. Pesquisa Agropecuária Brasileira, 49:449-456.

Caron BO, Sgarbossa J, Schwerz F, Elli EF \& Eloy E (2018) Dynamics of solar radiation and soybean yield in agroforestry systems. Anais da Academia Brasileira de Ciências, 90:37993812 .

Carvalho PER (2002) Canafístula. Colombo, Embrapa Florestas. 15p. (Circular Técnica, 64)

CONAB - Companhia Nacional de Abastecimento (2019) Acompanhamento da safra brasileira de grãos - Terceiro levantamento. Brasília, Conab. 142p.

Cordeiro LAM, Vilela L, Marchão RL, Kluthcouski J \& Martha Júnior GB (2015) Integração lavoura-pecuária e integração lavoura-pecuária-floresta: estratégias para intensificação sustentável do uso do solo. Cadernos de Ciência \& Tecnologia, 32:1553.

CQFS - Comissão de Química e Fertilidade do Solo (2004) Manual de calagem e adubação para os estados do Rio Grande do Sul e Santa Catarina. 10 a ed. Porto Alegre, CQFS. 401p.

Diel D, Behlin M, Farias Neto AL \& Isemhagen ECC (2014) Distribuição horizontal e vertical de fósforo em sistemas de cultivos exclusivos de soja e de integração lavoura-pecuáriafloresta. Pesquisa Agropecuária Brasileira, 49:639-647.

Doorenbos J \& Kassam AH (1994) Efeito da água no rendimento das culturas. Campina Grande, UFPB. 306p.

Duan ZP, Gan YW, Wang BJ, Hao XD, Xu WL, Zhang W \& Li LH (2019) Interspecific interaction alters root morphology in young walnut/wheat agroforestry systems in northwest China. Agroforestry Systems 93:419-434.

Embrapa - Empresa Brasileira de Pesquisa Agropecuária (2006) Tecnologias de produção de soja - Paraná - 2007. Londrina, Embrapa Soja. 217p.

Embrapa - Empresa Brasileira de Pesquisa Agropecuária (2013) Tecnologias de produção de soja-Região Central do Brasil 2014 Londrina, Embrapa Soja. 266 p.

Fagan BF, Dourado Neto D, Vivia R, Franco RB, Yeda MP, Massignam LF, Oliveira RF \& Martins KV (2013) Efeito da aplicação de piraclostrobina na taxa fotossintética, respiração, atividade da enzima nitrato redutase e produtividade de grãos de soja. Bragantia, 69:771-777.

Franchini JC, Balbinot Junior AA, Sichieri FR, Debiasi H \& Conte O (2014) Yield of soybean, pasture and wood in integrated crop-livestock-forest system in Northwestern Paraná state, Brazil. Revista Ciência Agronômica, 45:1006-1013.

Gaspar AP, Laboski CAM, Naeve SL \& Conleu SP (2017) Dry matter and nitrogen uptake, partitioning, and removal across a wid range of soybean seed yield levels. Crop Science, 57:21702182 .

Macedo RLG, Bezerra RG, Venturin N, Salgado BG, Vale RS \& Higashikawa (2004) Produção agroflorestal de sistemas consorciados de soja com clones de eucalipto na Região do cerrado, em Paracatu - Minas Gerais. Agrossilvicultura, 1:175-185.

Monteith JL (1977) Cimate and the efficiency of crop production em Britain. Philosophical Transactions of the Royal Society of London, 281:277-294.
Paciullo DSC, Carvalho CAB, Aroeira LJM, Morenz MJF, Lopes FCF \& Rossiello ROP (2007) Morfologia e valor nutritivo do capim-braquiária sob sombreamento natural e a sol pleno. Pesquisa Agropecuária Brasileira, 42:573-579.

Petter FA, Silva JÁ, Zuffo AM, Andrade FR, Pacheco LP \& Almeida FA (2016) Elevada densidade de semeadura aumenta a produtividade da soja? Respostas da radiação fotossinteticamente ativa. Bragantia, 75:173-183.

Porras CA, Caýon DG \& Delgado OA (1997) Comportamiento fisiológico de genótipos de soya em diferentes arreglos de siembra. Acta Agronomiza 47:09-15.

SAS Institute INC. (2003) Statical Analysis System user's guide. Version 8.0. Carry, Statical Anaçysis System Institute. 200p.

Schmidt D, Caron BO, Pilau J, Nardino M \& Elli ELF (2017) Morfoanatomia foliar de azevém no sub-bosque de espécies arbóreas em sistemas agroflorestais. Revista Ceres, 64:368-375.

Schwerz F, Medeiros SLP, Elli EF, Eloy E, Sgarbossa J \& Caron BO (2018) Plant growth, radiation use efficiency and yield of sugarcane cultivated in agroforestry systems: $\mathrm{Na}$ alternative for threatened ecosystems. Anais da Academia Brasileira de Ciências, 90:3265-3283.

Sgarbossa J, Schwerz F, Elli EF, Tibollsa LB, Schmidt D \& Caron BO (2018) Agroforestry systems and their effects on the dynamics of solar radiation and soybean yield. Comunicata Scientiae, 9:492-502.

Singer JW, Meek DW, Sauer TJ, Prueger JH \& Hatfield JL (2011) Variability of light interception and radiation use effiicnecy in maize and soybean. Field Crops Research, 121:147-152.

Soyl Survery Staff (2014) Keys to Soil Taxonomy. 12 edition. Whashington, USDA. 355p.

Taiz L, Zeiger E, Moller IM \& Murphy A (2017) Fisiologia e Desenvolvimento Vegetal. $6^{\mathrm{a}}$ ed. Porto Alegre, Artmed. 808p.

Thornthwaite CW \& Mather JR (1995) The water balance Publications in climatology. Centerton, Drexel Institute of Technology - Laboratory of Climatology. 104p.

Van Heerden PDR, Donaldson RA, Watt DA \& Singels A (2010) Biomass accumulation in sugarcane: unravelling the fator underpinning reduced growth phenomena. Journal of Experimental Botany, 61:2877-2887.

Van Roekel RJ \& Puercell LC (2014) Soybean biomass and nitrogen accumulation rates and radiativo use efficiency in a maximum yield environment. Crop Science, 54:1189-1196.

Varella AC, Moot DJ, Pollock KM, Peri PL \& Lucas RJ (2010) Do light and alfalfa responses to cloth and slatted shade represent those measured under an agroforestry system? Agroforestry Systems, 81:157-173.

Varlet-Grancher CG, Gosse M, Chartier H, Sinoquet R, Bonhomme R \& Allirand JM (1989) Mise na point: rayinnement solarie absorvé ou intercepté par um couvert vegetal. Agronomie, 9:419-439.

Wang BJ, Zhang W, Ahanbieke P, Gan YW, Xu WL, Li LH, Christie P \& Li L (2014) Interspecific interactions alter root length density, root diameter and specific root length in jujube/wheat agroforestry systems. Agroforestry Systems, 88:835-850.

Werner F, Balbinot AAJ, Franchini JC, Ferreira AS \& Silva MAA (2017) Agronomic performance of soybean cultivars in na agroforestry system. Pesquisa Agropecuária Tropical, 47:279285.

Wink C, Monteiro JS, Reinert DJ \& Liberalesso E (2012) Parâmetros da copa e sua relação com o diâmetro e altura das árvores de eucalipto em diferentes idades. Scientia Florestalis, 40:057-067.

Rev. Ceres, Viçosa, v. 67, n.3, p. 165-175, may/jun, 2020 
Zhang W, Ahanbieke P, Wang B, Gan Y, Li L, Christie P \& Li L (2014) Temporal and spatial distribution of roots as affected by interspecific interactions in a young walnut/wheat alley cropping system in northwest China. Agroforestry Systems, 89:327-343.

Zhang W, Ahanbieke P, Wang B, Xu W, Li L, Christie P \& Li L (2013) Root distribution and interactions in jujube tree/wheat agroforestry system. Agroforestry Systems 87:929-939.
Zhang W, Wang B, Gan Y, Duan Z, Hao X, Xu W, Lv X \& Li L (2016) Competitive interaction in a jujube tree/wheat agroforestry system in northwest China's Xinjiang Province. Agroforestry Systems, 91:811-893.

Zhang W, Wang BJ, Gan YW, Duan ZP, Hao XD, Xu WL \& Li LH (2019) Competitive interaction in jujube tree/cotton agroforestry system in Xinjiang province, northwestern China. Agroforestry Systems, 93:591-605. 